\title{
Design of the FOTS cable right-of-way on the territory of the Meshchersky National Park with- in the borders of the Ryazan and Vladimir re- gions
}

\author{
Vitaly Isaychev ${ }^{1}$, Olga Tsapovskaya ${ }^{2}$,Elena Provalova, ${ }^{2,}$, Sergey Yerofeev ${ }^{2}$, and Oksana \\ Khamzina ${ }^{3}$ \\ ${ }^{1}$ Department of Biology, Chemistry and Storage and processing technology for crop products, FSBEI \\ HE Ulyanovsk SAU, Ulyanovsk, Russia \\ ${ }^{2}$ Department of land management and cadastre, FSBEI HE Ulyanovsk SAU, Ulyanovsk, Russia \\ ${ }^{3}$ Department of economic security, accounting and audit, FSBEI HE Ulyanovsk SAU, Ulyanovsk, \\ Russia
}

\begin{abstract}
The article discusses the issue of designing a fiber-optic transmission system (FORS) cable right-of-way on the territory of the Meshchersky National Park within the borders of the Ryazan and Vladimir regions. At the moment, land plots adjacent to both sides of the right-of-way may be privately owned, and changing the boundaries of the right-of-way, if necessary, may be associated with significant difficulties. Consequently, the land owner has the right to demand payment for restrictions in his economic activities on these lands provided for by the status of "protected zone". In addition, the work pays attention to the protection of forests during the design of the cable right-of-way, since the reproduction of forests is extremely important in forests protection. In this paper, there are references to the legal documents used in the course of the study.
\end{abstract}

\section{Introduction}

According to literature sources, "...at present, in design practice, the width of the rightof-way is considered as a derivative of design decisions on the location of the object, their "geometry", without taking into account factors affecting the amount of land reservation, the state of the geological environment, terrain features, traffic composition, and other natural and man-made conditions." [6] With this approach to justification of the right-of-way width, it is not possible to establish the priority influence of any of the listed factors. The methodology for justifying the size of the right-of-way, depending on the form of land ownership, is also not developed, since until the 90s of the last century, whole land was either in state or collective farm ownership. [1,3] This problem is compounded by the reform of the state's land policy.

As some researchers write, "...currently, land plots adjacent to both sides of the right-ofway may be privately owned, and changing the boundaries of the right-of-way, if neces-

\footnotetext{
${ }^{*}$ Corresponding author: provalova2013@yandex.ru
} 
sary, may be associated with significant difficulties. The land owner has the right to demand payment for restrictions in his economic activity on these lands provided for by the status of a "protected zone". "[4,5]

In our case, the object of this study is a right-of-way, which should be understood as a strip of land intended for laying fiber-optic transmission system (FOTS) cable on the territory of the Meshchersky National Park within the borders of the Ryazan and Vladimir regions.

\section{Materials and methods of research}

Meshchersky National Park is located in the South-Central part of the Meshchersky lowland in the subtaiga zone of mixed (coniferous-broad-leaved) forests.

Geomorphologically, the projected section of the Yaroslavl - Meshiha - Nizhny Novgorod highway is located on a slightly rounded accumulative plain, which mainly reflects the tectonic elements of the Russian platform and is complicated by the erosionaccumulative relief of river valleys, gullies and gills.

The entire territory under consideration can be attributed to a moderate continental climate zone with moderately warm summers and moderately harsh and snowy winters. Cyclonic activity prevails for most of the year. [7]

The planned section of the FOTS is located in the central part of the Russian plain, the general direction of the highway is from North-West to South-East.

The highway runs mainly within the South-Eastern wing of the Moscow tectonic depression, in its South-Eastern part - along the adjacent Tokmovsky arch. This determines the structure of the upper part of the geological section, where the thickness of quaternary deposits of variegated facies composition is underlain by carboniferous carbonate or terrigene brockrams.

Underground oil trunk pipelines run through the Moscow, Ryazan, Tula, Kaluga, Orel regions and the city of Moscow:

- "Moscow oil refinery plant" - of the linear production and dispatching station (LPDS) "Volodarskaya", "Circle oil products pipeline around Moscow" and its branches to airports and oil depots operated by the Volodarskoe district oil product pipeline Department (DOPDV);

- "Ryazan-Moscow", "Novki-Ryazan", "Ryazan-Tula-Orel" and their branches to the airport and oil depots operated by the Ryazan regional oil pipeline Department (RRPD).

Underground oil products pipelines are a complex technical structure operating under high pressure. The structure of the main oil product pipelines includes the pipeline itself, including bends, high-pressure valves, control and measuring columns, cathodic and drainage protection stations, tread protection, block boxes of control and operation points (COP) and other equipment important for the operation of oil products pipelines. The route of oil products pipelines marked with signs "Beware of the oil products pipeline!", at the intersection of highways - with П-shaped signs "Beware of the oil products pipeline!" and road signs prohibiting stopping in the protected zone of the oil products pipelines.

The new cable will consist of fiber-optic material. It compares favorably with copper with the speed of information transfer, as well as it is cheaper and more durable in operation.

The main difficulty in designing a new cable was the following: part of the forests was assigned the status of national parks, and this is land specially protected by the state and any construction in them is prohibited, including new cable laying. It is necessary to design a new cable bypassing the Meshchersky National Park.

The design was carried out on the principle of the shortest path along the Park, without entering the protected area of the National Park, mainly on the land of the State Forest Fund 
(SFF), also part of the cable fell into the land of settlements, industrial land and agricultural land. Then the project was designed, geological, geodetic, and environmental surveys were carried out. After the procedure of coordination with the Ministry of Nature Management, rural administrations and individuals, if necessary, the cable was set out and the axis and the right-of-way were fixed on the ground for detailed identification:

- in the case of SFF - the species, quality, composition, density and other indicators of wood, as well as to avoid cutting down red book trees, and cutting down trees in which red book animals live;

- in the case of agricultural land - identification of actual use, if any, establishment of crops and land productivity for the purpose of calculating further rent.

Before any design, geodetic surveys are performed, the purpose of which is to identify all communications, terrain marks, object details, etc.

In accordance with the terms of reference for lot No. 2-38. 3/OZK OIPiEIS-05.2018 "Implementation of a complex of cadastral works on the development and approval of documentation on the territory planning (DTP) and registration of rights to land plots for the period of construction and installation work on the object "Fiber-optic transmission system (FOTS) Ryazan Novki. Construction. First stage" a list and content of the main data and requirements for the work were developed.

The purpose of the work is to perform a complex of cadastral works on the development and approval of the DTP and registration of rights to land plots for construction and installation works on the object of the UIS PJSC Transneft "Fiber-optic transmission system (FOTS) Ryazan-Novki. Construction. First stage".

Location of the object - the Vladimir region, the Ryazan region.

The work was performed in accordance with the requirements of regulatory and technical documents:

- Technical specification;

- "The list of information subject to classification by the Ministry of Energy of Russia" approved by Order of Ministry of Energy of the RF on 19.10.2017, No. 26c;

- The Land code of the Russian Federation No. 136-FZ of dated October 25, 2001;

- The Forest code of the Russian Federation No. 200-FZ dated 04.12.2006;

- Urban Planning Code of the Russian Federation No. 190-f dated 29.12.2004);

- Federal law dated July 13, 2015 "On state registration of real estate" No. 218-FZ;

- Federal law dated 18.06.2001 "On land management" No. 78-FZ;

- Law of the Russian Federation daetd 21.07.1993 "On state secrets" No. 5485-I;

- Order of the Ministry of Natural Resources of the Russian Federation and Russian Federation Committee on Land Resources and Land Management dated December 22, 1995 No. 525/67 "On approval of the main provisions on land reclamation, removal, conservation and rational use of the fertile soil layer";

- Safety regulations for topographic and geodetic works. PTB-88;

- Order of the Ministry of Economic Development of the Russian Federation dated 24.11.2008, № 412 "On approval of the form of a survey plan and requirements to its preparation, sample form of the notice of the meeting and agreement about the location of land boundaries" (along with the "Requirements for the preparation of survey plan";

- The scheme of territorial planning of the Russian Federation in the field of federal transport (in terms of pipeline transport), approved by the Order of the Government of the Russian Federation dated 13.08.2013. No. 1416-r;

- Decree of the Government of the Russian Federation No. 77 dated 15.02.2011 "On the procedure for preparing documentation on territory planning carried out by the decision of the authorized federal executive body";

- Industry regulations of JSC "AC "Transneft" OR-03.100.60-KTN-088-15" Procedure for the organization of work on registration of rights to land plots for design and survey, 
construction and installation works, operation of objects of TPD, CR and IP of JSC "AC "Transneft" (with amendments and additions);

- Local regulations;

- Other regulatory documents required to complete the technical specification. [8]

Materials for the development and approval of the DTP, preliminary approval of the provision of land (forest) plots was a land management case for the allotment of land for the period of construction and installation works (CIW) (on paper in 1 copy in electronic form on CD (DVD) media in .pdf format), including the following documentation:

1. Preliminary agreements with owners, landowners, land users, tenants on the terms of use and restoration of land plots in at least 2 copies;

2. Agreed and approved in established order the Certificate of full-scale technical survey and/or project documentation on the forest plot, with the application of the Decision approving the Certificate of the full-scale technical survey and/or project documentation to the forest plot, 1 copy, certified 1 copy;

3. Agreed and approved documentation on the territory planning (planning project, land surveying project) on paper at least 2 copies, and in electronic form on CD (DVD)-R/RW in 2 copies (text part in the development format, graphic material in vector form in the format of GIS AutoCAD (.dwg) and MapInfo, as well as in PDF format);

5. Decision of the Executive body of state power or local self-government on approval of documentation on the territory planning - at least 2 copies;

6. Publication materials in the media about the upcoming construction - at least 2 copies (if necessary);

7. A decision on preliminary approval of the provision of a land (forest) plot - 1 copy.

\section{Results and discussions}

After project approval, the procedure for removing the axis and the security zone to the area follows, the points of state geodetic networks (SGS) are pre-ordered, and the coordinate system is calibrated. For work, at least 5 SGS points for each cadastral area are needed where the work is carried out.

After the survey of points, they must be linked to each other, if the discrepancy exceeds any points in the plan or by height, they must be excluded and new ones must be examined. Based on the results of the survey, a survey card is filled in and the data are submitted to the Federal Service for State Registration, Cadastre and Cartography (Rosreestr). After the calibration process, the characteristic points are set out and fixed on the ground.

Scope of work: number of municipalities - 7 (Table 1).

Table 1. Scope of work: number of municipalities.

\begin{tabular}{|c|c|c|}
\hline No. & Vladimir region & Ryazan region \\
\hline 1 & Kameshkovskiy district & Klepikovskiy district \\
\hline 2 & Sudogodskiy district & Spasskiy district \\
\hline 3 & Gus-Khrustalny district & Ryazan district \\
\hline 4 & - & Ryazan \\
\hline
\end{tabular}

Number of right holders is shown in table 2. 
Table 2. Number of right holders.

\begin{tabular}{|c|c|c|}
\hline No. & District & Number of right holders: \\
\hline \multicolumn{3}{|r|}{ Vladimir region } \\
\hline 1 & Kameshkovskiy district & $\begin{array}{l}\text { total: } 1 \text { land users, including FF - } 1 \text { out of the total } \\
\text { number - for cadastral registration and land surveying: } \\
\text { 1, including the forest fund (hereinafter - FF) - } 1\end{array}$ \\
\hline 2 & Sudogodskiy district & $\begin{array}{l}\text { total: } 7 \text { land users, including FF - } 2 \text { out of the total } \\
\text { number - for cadastral registration and land surveying: } \\
\text { 4, including FF - } 2\end{array}$ \\
\hline 3 & Gus-Khrustalny district & $\begin{array}{l}\text { total: } 9 \text { land users, including FF - } 2 \text { out of the total number } \\
\text { - for cadastral registration and land surveying: } 4 \text {, including } \\
\text { FF - } 2\end{array}$ \\
\hline \multicolumn{3}{|r|}{ Ryazan region } \\
\hline 4 & Klepikovskiy district & $\begin{array}{l}\text { total: } 17 \text { land users, including FF - } 2 \text { out of the total } \\
\text { number - for cadastral registration and land surveying: } \\
\text { 5, including FF - } 2\end{array}$ \\
\hline 5 & Spasskiy district & $\begin{array}{l}\text { total: } 6 \text { land users, including FF - } 1 \text { out of the total } \\
\text { number - for cadastral registration and land surveying: } \\
\text { 2, including FF - } 1\end{array}$ \\
\hline 6 & Ryazan district & $\begin{array}{l}\text { total: } 53 \text { land users, including FF - } 2 \text { out of the total } \\
\text { number - for cadastral registration and land surveying: } \\
\text { 7, including FF - } 2\end{array}$ \\
\hline 7 & city of Ryazan & $\begin{array}{l}\text { total: } 21 \text { land users, including FF - } 0 \text { out of the total } \\
\text { number - for cadastral registration and land surveying: } \\
\text { 12, including FF - } 0\end{array}$ \\
\hline
\end{tabular}

Total length of the linear object in the Vladimir region: $107.388 \mathrm{~km}$.

Total length of the linear object in the Ryazan region: $143.693 \mathrm{~km}$.

Allotment land in the Vladimir region includes agricultural land, forest land, and industrial land.

On the territory of the Ryazan region, allotment land includes agricultural land, forest land, industrial land, and lands of settlements.

The area of allocated land plots in the Vladimir and Ryazan regions, broken down by land category (ha) / length of system object, broken down by land category $(\mathrm{km})$, is shown in table 3 .

Table 3. The area of the allocated LP, broken down by land category (ha) / length of the system object, broken down by land category $(\mathrm{km})$.

\begin{tabular}{|l|l|l|}
\hline No. & \multicolumn{1}{|c|}{ Land category } & \multicolumn{1}{c|}{ Area of allocated LP } \\
\hline \multicolumn{1}{|c|}{\begin{tabular}{l} 
Vladimir region \\
\hline
\end{tabular}} & $\begin{array}{l}\text { Lands agriculture pur- } \\
\text { of }\end{array}$ & $\begin{array}{l}\text { Total }-6.1200 \mathrm{ha} / 10.200 \mathrm{~km}, \text { including for cadastral } \\
\text { registration and surveying } 5,4000 \mathrm{ha} / 9.000 \mathrm{~km} .\end{array}$ \\
\hline 2 & $\begin{array}{l}\text { Lands of the forest } \\
\text { fund }\end{array}$ & $\begin{array}{l}\text { Total }-58.0866 \mathrm{ha} / 96.811 \mathrm{~km}, \text { including cadastral regis- } \\
\text { tration and land surveying } 58,0866 \text { ha } / 96.811 \mathrm{~km} .\end{array}$ \\
\hline 3 & $\begin{array}{l}\text { Lands } \\
\text { of industrial purposes }\end{array}$ & $\begin{array}{l}\text { Total }-0.2262 \text { ha } / 0.377 \mathrm{~km}(\text { cadastral registration is not } \\
\text { required). }\end{array}$ \\
\hline \multicolumn{2}{|c|}{ Ryazan region } \\
\hline
\end{tabular}




\begin{tabular}{|l|l|l|}
\hline 4 & $\begin{array}{l}\text { Lands of agriculture } \\
\text { purposes }\end{array}$ & $\begin{array}{l}\text { Total }-26.8056 \mathrm{ha} / 44.676 \mathrm{~km} \text {, including for cadastral } \\
\text { registration and land surveying } 8.0244 \mathrm{ha} / 13.374 \mathrm{~km} .\end{array}$ \\
\hline 5 & $\begin{array}{l}\text { Lands of the forest } \\
\text { fund }\end{array}$ & $\begin{array}{l}\text { Total }-51.7344 \mathrm{ha} / 86.224 \mathrm{~km}, \text { including cadastral regis- } \\
\text { tration and land surveying } 51.7344 \text { ha } / 86.224 \mathrm{~km} .\end{array}$ \\
\hline 6 & $\begin{array}{l}\text { Lands of industrial } \\
\text { purposes }\end{array}$ & $\begin{array}{l}\text { Total }-0.6288 \mathrm{ha} / 1.048 \mathrm{~km}(\text { cadastral registration is not } \\
\text { required). }\end{array}$ \\
\hline 7 & $\begin{array}{l}\text { Settlement lands } \\
\text { letal }-7.047 \mathrm{ha} / 11.745 \mathrm{~km} \text {, including for cadastral reg- } \\
\text { istration and land surveying } 4.347 \mathrm{ha} / 7.245 \mathrm{~km} .\end{array}$ \\
\hline
\end{tabular}

The analysis of table 3 shows that a larger number of lands falling within the allotment zone belong to the lands of the forest fund, both on the territory of the Vladimir and Ryazan regions.

The length of the borders of the LP $(\mathrm{km})$ with a breakdown by land category (ha) on the territory of the Vladimir and Ryazan regions is shown in table 4.

Table 4. LP borders length $(\mathrm{km})$.

\begin{tabular}{|c|c|c|}
\hline No. & Land category & LP borders length (km). \\
\hline \multicolumn{3}{|r|}{ Vladimir region } \\
\hline 1 & $\begin{array}{l}\text { Lands of agriculture pur- } \\
\text { poses }\end{array}$ & $\begin{array}{l}\text { Total }-20.400 \mathrm{~km} \text {, including } \\
18.000 \mathrm{~km} \text { for cadastral registration and land survey- } \\
\text { ing. }\end{array}$ \\
\hline 2 & Lands of the forest fund & $\begin{array}{l}\text { Total }-193.622 \mathrm{~km} \text {, including } \\
193.622 \mathrm{~km} \text { for cadastral registration and land sur- } \\
\text { veying. }\end{array}$ \\
\hline 3 & $\begin{array}{l}\text { Lands } \\
\text { of industrial purposes: }\end{array}$ & $\begin{array}{l}\text { Total - } 0.754 \mathrm{~km} \text { (cadastral registration is not re- } \\
\text { quired). }\end{array}$ \\
\hline \multicolumn{3}{|r|}{ Ryazan region } \\
\hline 4 & $\begin{array}{l}\text { Lands of agriculture pur- } \\
\text { poses }\end{array}$ & $\begin{array}{l}\text { Total }-89.352 \mathrm{~km} \text {, including } 26.748 \mathrm{~km} \text { for cadas- } \\
\text { tral registration and land surveying. }\end{array}$ \\
\hline 5 & Lands of the forest fund & $\begin{array}{l}\text { Total - } 172.448 \mathrm{~km} \text {, including cadastral registration } \\
\text { and land surveying } 172.448 \mathrm{~km} \text {. }\end{array}$ \\
\hline 6 & $\begin{array}{l}\text { Lands of industrial pur- } \\
\text { poses }\end{array}$ & $\begin{array}{l}\text { Total - } 2.096 \mathrm{~km} \text { (cadastral registration is not re- } \\
\text { quired). }\end{array}$ \\
\hline 7 & Settlement lands & $\begin{array}{l}\text { Total }-23.49 \mathrm{~km} \text {, including } 14.49 \mathrm{~km} \text { for cadastral } \\
\text { registration and land surveying. }\end{array}$ \\
\hline
\end{tabular}

The number of separate land plots for each municipality is shown separately in table 5 .

Table 5. Number of separate plots.

\begin{tabular}{|c|l|l|}
\hline No. & \multicolumn{1}{|c|}{ District } & \multicolumn{1}{c|}{ Number of separate plots } \\
\hline \multicolumn{2}{|c|}{ Vladimir region - 52 } \\
\hline 1 & Kameshkovskiy district & $\begin{array}{l}\text { 1, including out of the total number - for cadastral } \\
\text { registration and land surveying: } \\
1, \text { including FF - 1 }\end{array}$ \\
\hline 2 & Sudogodskiy district & $\begin{array}{l}19, \text { including out of the total number - for cadastral } \\
\text { registration and land surveying: } \\
17, \text { including FF - 14 }\end{array}$ \\
\hline 3 & Gus-Khrustalny district & $\begin{array}{l}32 \text {, including out of the total number - for cadastral } \\
\text { registration and land surveying: } \\
23, \text { including FF - 20 }\end{array}$ \\
\hline
\end{tabular}




\begin{tabular}{|c|l|l|}
\hline \multicolumn{2}{|c|}{ Ryazan region - 179 } \\
\hline 4 & Klepikovskiy district & $\begin{array}{l}31, \text { including out of the total number - for cadastral } \\
\text { registration and land surveying: } \\
15, \text { including FF - 11 }\end{array}$ \\
\hline 5 & Spasskiy district & $\begin{array}{l}10, \text { including out of the total number - for cadastral } \\
\text { registration and land surveying: } \\
\text { 6, including FF - 4 }\end{array}$ \\
\hline 6 & Ryazan district & $\begin{array}{l}93, \text { including out of the total number - for cadastral } \\
\text { registration and land surveying: } \\
30, \text { including FF - } 8\end{array}$ \\
\hline 7 & city of Ryazan & $\begin{array}{l}45, \text { including out of the total number - for cadastral } \\
\text { registration and land surveying: } \\
12, \text { including FF - 0. }\end{array}$ \\
\hline
\end{tabular}

In accordance with part 1 of article 61 of the LC of the Russian Federation "... cut down, dead, damaged forests are subject to reproduction. Forest reproduction is carried out by reforestation and forest care..». [2]

In accordance with the above-mentioned Federal law: "...measures for forest reproduction are fixed in the forest management regulations and in the forest development project. Measures for forests reproduction are of great importance. Failure by citizens, legal entities that use forests, to compy with forestry regulations and a forest development project in terms of forest reproduction is the basis for early termination of lease agreements for forest plots, contracts for the sale and purchase of forest plantations, as well as for compulsory termination of the right to permanent (unlimited) use of forest plots or the right of gratuitous fixed-term use of forest plots".

But in our case, since the cable is not serviced, forest reproduction will take place naturally, i.e. the cut-down right-of-way will overgrow independently, reclamation actions are not required.

\section{Conclusions}

Thus, the main difficulty in designing a new cable was the following: part of the forests was assigned the status of national parks, and this is land specially protected by the state and any construction in them is prohibited, including new cable laying. It is necessary to design a new cable bypassing the Meshchersky National Park. The design was carried out on the principle of the shortest path along the Park, without entering the protected area of the National Park, mainly on the land of the State Forest Fund (SFF), also part of the cable fell into the land of settlements, industrial land and agricultural land. Then the project was designed, geological, geodetic, and environmental surveys were carried out. After the procedure of coordination with the Ministry of Nature Management, rural administrations and individuals, if necessary, the cable was set out and the axis and the right-of-way were fixed on the ground for detailed identification:

- in the case of State Forest Fund (SFF) - the species, quality, composition, density and other indicators of wood, as well as to avoid cutting down red book trees, and cutting down trees in which red book animals live;

- in the case of agricultural lands - identification of actual use, if any, establishment of crops and land productivity for the purpose of calculating further rent.

Before any design, geodetic surveys are performed, the purpose of which is to identify all communications, terrain marks, object details, etc. 


\section{References}

1. The Land code of the Russian Federation, Federal law No. 136-FZ dated 25.10.2001, Consultant Plus System

2. The Forest code of the Russian Federation, Federal law No. 200-FZ dated 04.12.2006, Consultant Plus System

3. On land management, Federal law No. 78-FZ dated 18.06.2001, Consultant Plus System

4. V.N. Grechikhin, E.V. Provalova, Land resources and problems of their use, Agrarian science and education at the present stage of development: experience, problems and ways to solve them: materials of the VI International Scientific and Practical Conference (Ulyanovsk, 2015)

5. E.V. Privalova, O.N. Tsapovskaya, O.I. Syundyukov, Improving the efficiency of cadastral activities and the quality of cadastral works, Materials of the VIII International Scientific and Practical Conference dedicated to the 75th Anniversary of the Ulyanovsk State Agrarian University named after P.A. Stolypin: agricultural science and education at the present stage of development: experience, problems and ways to solve them (2017)

6. E.V. Provalova, S.E. Yerofeev, Yu.V. Yermoshkin, S.V. Shaykin, Land management, cadastre and land monitoring, 4(159), 25-32 (2018)

7. E.V. Provalova, M.N. Lukyanova, O.V. Skrobotova, R.M. Ivanova, Journal of environmental management and tourism, 4, 809-818 (2019)

8. Universal legal system "Consultant Plus", Access mode: http://www.consultant.ru 